\title{
Regimen Used to Treat Non-Small Cell Lung Carcinoma
}

National Cancer Institute

\section{Source}

National Cancer Institute. Regimen Used to Treat Non-Small Cell Lung Carcinoma. NCI

Thesaurus. Code C63360.

Any regimen that can be used for the treatment of non-small cell lung carcinoma

(NSCLC). 